\title{
Evaluation of microRNA expression in head and neck squamous cell carcinoma cell lines and in primary culture of oral keratinocytes
}

\author{
Avaliação da expressão de microRNAs em linhagens celulares de carcinoma epidermoide \\ de cabeça e pescoço e em cultura primária de queratinócitos orais
}

\author{
Flavia Maziero Andreghetto ${ }^{1}$, Maria Fatima Guarizo Klingbeil2 ${ }^{2}$, Renata Machado Soares ${ }^{3}$, Roberta Sitnik ${ }^{4}$, \\ Décio dos Santos Pinto Junior ${ }^{5}$, Monica Beatriz Mathor ${ }^{2}$, Fabio Daumas Nunes ${ }^{5}$, Patricia Severino ${ }^{1}$
}

\begin{abstract}
Objective: Functional in vitro studies are fundamental to understand the role of microRNAs, small non coding RNA molecules that function as post-transcriptional regulators, in cancer. The objective of this study was to determine the applicability of head and neck squamous cell carcinoma cell lines and human oral keratinocytes as models for functional studies on microRNAs previously identified as deregulated in head and neck squamous cell carcinomas. Methods: The expression level of four microRNAs was assessed in cell lines and in primary cultures of oral keratinocytes using specific real-time polymerase chain reactions. The identity of oral squamous cell carcinoma cell lines was confirmed by means of STR (short tandem repeats) profiling. The possible impact of feeder-layer gene expression in global microRNA expression results from keratinocyte primary culture was also evaluated. Results: Significant differences in microRNA gene expression were observed among squamous cell carcinoma cell lines, particularly among cells lines from distinct subsites, as well as between primary culture of human keratinocytes and immortalized keratinocyte cell lines. Conclusions: Primary cultures of human keratinocytes and diverse tumor cell lines are relatively easy to obtain. However, each cell model possesses a characteristic phenotype; whereas one may be useful for a specific study, it may be inappropriate for another. Therefore, it is imperative that suitable cell lines are cautiously selected for functional studies in cancer.
\end{abstract}

Keywords: Gene expression; Keratinocytes; Carcinoma, squamous cell; Head and neck neoplasms

\section{RESUMO}

Objetivo: Estudos funcionais in vitro são essenciais para a compreensão do papel de microRNAs, pequenas moléculas de RNA que desempenham papel importante na regulação gênica, no câncer. Neste estudo, analisamos a viabilidade de linhagens celulares derivadas de carcinoma epidermoide de cabeça e pescoço, queratinócitos orais provenientes de culturas primárias e queratinócitos imortalizados, como modelos para estudos funcionais de microRNAs previamente identificados como desregulados nesse tipo de carcinoma. Métodos: Avaliamos a expressão de quatro microRNAs em linhagens celulares e em cultura primária de queratinócitos orais por meio de reações em cadeia da polimerase em tempo real. As linhagens celulares de carcinoma epidermoide de boca foram previamente caracterizadas quanto ao seu perfil de sequências de DNA do tipo STR (do inglês short tandem repeats ou repetições curtas em sequência) com 0 objetivo de confirmar a identidade da linhagem. Avaliamos ainda a possível influência da expressão gênica detectada na camada de sustentação usada no cultivo de queratinócitos no resultado global obtido. Resultados: Nossos resultados apontam diferenças significativas na expressão dos microRNAs entre linhagens celulares passíveis de serem utilizadas como modelos para estudos funcionais em carcinoma epidermoide de cabeça e pescoço. Ressaltam-se diferenças entre linhagens de carcinoma de língua e de faringe, bem como diferenças expressivas entre a linhagem de queratinócitos orais imortalizados e queratinócitos orais normais provenientes de culturas primárias. Conclusão: Culturas primárias de queratinócitos orais bem como linhagens tumorais são obtidas de forma relativamente simples.

\footnotetext{
Study carried out at the Centro de Pesquisa Experimental do Instituto Israelita de Ensino e Pesquisa Albert Einstein - IIEPAE, São Paulo (SP), Brazil; in collaboration with the Laboratório de Técnicas Especiais, Hospital Israelita Albert Einstein - HIAE, São Paulo (SP), Brazil; Faculdade de Odontologia da Universidade de São Paulo - USP, São Paulo (SP) Brazil; Centro de Tecnologia das Radiações, Instituto de Pesquisas Energéticas e Nucleares - São Paulo (SP), Brazil.

${ }^{1}$ Centro de Pesquisa Experimental do Instituto Israelita de Ensino e Pesquisa Albert Einstein - IIEPAE, São Paulo (SP), Brazil; Department of Estomatology, Faculdade de Odontologia, Universidade de São Paulo - USP, São Paulo (SP), Brazil.

${ }^{2}$ Centro de Tecnologia das Radiações, Instituto de Pesquisas Energéticas e Nucleares - São Paulo (SP), Brazil.

${ }^{3}$ Centro de Pesquisa Experimental, Instituto Israelita de Ensino e Pesquisa Albert Einstein - IIEPAE, São Paulo (SP), Brazil.

${ }^{4}$ Laboratório de Técnicas Especiais, Hospital Israelita Albert Einstein - HIAE, São Paulo (SP), Brazil.

${ }^{5}$ Department of Estomatology, Faculdade de Odontologia, Universidade de São Paulo - USP, São Paulo (SP), Brazil.

Corresponding author: Patrícia Severino - Avenida Albert Einstein, 627, 2SS, Bloco A - Morumbi - CEP 05652-000 - São Paulo (SP), Brazil - Tel.: (11) 2151-0507 - E-mail: psever@einstein.br

Received on: Jun 17, 2011 - Accepted on: Oct 19, 2011

Conflict of interest: none
} 
Entretanto, cada modelo celular possui características particulares que os tornam mais ou menos adequados para um determinado estudo. Conclui-se que a seleção cuidadosa das linhagens é fundamental para estudos funcionais sobre câncer.

Descritores: Expressão gênica; Queratinócitos; Carcinoma de células escamosas; Neoplasias de cabeça e pescoço

\section{INTRODUCTION}

Head and neck cancer is the sixth most common cancer in the world, and over $90 \%$ of these neoplasms are squamous cell carcinomas ${ }^{(1,2)}$. This tumor begins in the epithelium lining of the aerodigestive tract (oral cavity, nasal cavity, paranasal sinuses, pharynx and larynx). Epidemiological studies show a strong relation between head and neck squamous cell carcinoma and potential carcinogens, especially tobacco and alcohol ${ }^{(3,4)}$. Despite several advances in the treatment of head and neck squamous cell carcinoma, the five-year overall survival rate is one of the lowest among major cancers, with no significant improvement in the last two decades ${ }^{(5)}$. Currently, treatment planning is based mainly on the primary tumor site and the presence or absence of metastases upon diagnosis ${ }^{(6)}$.

Small non-coding RNA molecules called microRNAs (miRNAs) play a significant role in gene expression regulation and were associated with various cellular processes related to carcinogenesis and tumor progression $^{(7-9)}$. In silico predictions estimate that miRNAs regulate more than $30 \%$ of the protein-coding genes ${ }^{(10)}$. Their action in head and neck squamous cell carcinoma is still poorly understood, although recent studies point out a relation between miRNAs and the prognosis of the disease $^{(11-13)}$. It is believed that understanding the role of these molecules may contribute to a better molecular characterization of the disease.

In vitro functional studies are essential to understand the role of miRNAs in cancer.Functional studies on miRNAs can be performed using tools that are similar to those used for protein-coding genes. Over expression of miRNA allows the identification of phenotypes associated with gain of function, whereas gene inhibition allows the identification of phenotypes associated with loss of function. The combination of these two tools helps the identification not only of genes that are regulated by miRNAs, but also cell processes that are affected by specific miRNAs.

A key initial step in this approach is selecting the most appropriate cell model. Cell culture is a widely used model, because it allows the analysis of cell behavior in an environment that is isolated from the multitude of biological processes that occur in vivo. The use of cell lines that are certified by authorized sources ensures the quality of conclusions. However, research laboratories commonly keep several cell lines for their own use. As cross-contamination accidents may occur while handling these cells ${ }^{(14)}$, rigorous quality control procedures are essential. In this study, short tandem repeat (STR) profiling was used to determine the identity of the cell lines ${ }^{(15)}$. STRs are regions of the human genome composed of repetitions of short sequences of two to six nucleotides (e.g. AT), which may vary in the numbers of repeats (e.g. ATATATAT $=\mathrm{AT}_{4}$ ). The number of repeats at each locus is an inherited trait and can be used to characterize the DNA of individuals. There are characteristic STR loci in each human chromosome, and the use of multiple loci can identify individuals with a high degree of certainty, making this method very useful for forensic or paternity identification testing, as well as for the characterization of cell lines.

Commercial (or established) cell lines offer a better level of reproducibility and, consequently, of standardization, compared to primary cultures. However, primary cultures have the advantage of not presenting genetic changes associated with the process of obtaining immortalized lines or cancer-related changes present in carcinoma cell lines. Therefore, we used established cell lines as our study models, including an immortalized oral keratinocyte cell line often used as a normal cell model in the literature, and cell lines derived from head and neck squamous cell carcinoma. In parallel, we also used oral keratinocytes from primary cultures to evaluate the expression of miRNAs in the context of non-cancerous epithelial cells. These cells are grown on a support layer (feederlayer) composed of irradiated murine fibroblasts. The irradiation controls the fibroblast proliferation rate, so that their growth does not adversely affect the growth of the cells of interest, but it keeps their metabolism active, which contributes to the maintenance of the keratinocyte culture.

Previous results from our group identified the miRNAs miR-1 and miR-10b as less expressed in tumors, as compared to tumor-free tissue from the same patient, whereas miR-196 and miR-7 were more expressed in tumors (unpublished data). The role of these miRNAs in head and neck squamous cell carcinoma is unknown, although they can be found in the literature in the context of other cancers ${ }^{(16-19)}$.

\section{OBJECTIVE}

To evaluate the expression of miRNAs previously identified as deregulated in head and neck squamous cell 
carcinoma, in cell lines derived from this type of tumor, in human oral keratinocytes derived from primary culture, and in a known cell line of immortalized oral keratinocytes.

\section{METHODS}

\section{Culture of tumor cell lines}

Cell lines of human head and neck squamous cell carcinoma - SCC4, SCC9, and SCC25 (derived from squamous cell carcinoma of the tongue), and $\mathrm{FaDu}$ (cells derived from a primary lesion of squamous cell carcinoma of the hypopharynx) were generously donated by Dr. Decio dos Santos Pinto Jr and Dr. Fabio Daumas Nunes, Dentistry School, Universidade de São Paulo (USP), originally available through the ATCC (American Type Culture Collection).These cell lines were grown in a culture medium composed of: Dulbecco's modified Eagle medium (DMEM) (Sigma, cat. D6429) and Ham's F12 Medium (Gibco, cat. 11765) (at 1:1), containing $10 \%$ fetal bovine serum (Gibco cat. 12.657-029), penicillin (100 U/mL), streptomycin $(100 \mu \mathrm{g} / \mathrm{mL})$, gentamicin $(50 \mu \mathrm{g} / \mathrm{mL})$, amphotericin B $(2.5 \mu \mathrm{g} / \mathrm{mL})$, and glutamine $(4 \mathrm{mM})$ (Gibco BRL: 21.051-040), in flasks suitable for cell culture, and maintained in a humidified atmosphere containing $5 \% \mathrm{CO} 2$ at $37^{\circ} \mathrm{C}$.

\section{Oral keratinocyte culture}

Oral keratinocytes were obtained from primary cultures of the buccal mucosa, from voluntary donor patients undergoing surgery, such as removal of third molars, clinical crown lengthening and ulectomy, performed in out-patient clinics in the Dentistry School of USP ${ }^{(20)}$. The patients were informed and signed the required Informed Consent. This study was approved by the Research Ethics Committee of Instituto de Pesquisas Energéticas e Nucleares (IPEN/CNEN-SP) [Institute of Energy and Nuclear Research] (approval number 087/ CEP-IPEN/SP). Keratinocytes were grown in a culture medium composed of DMEM (Gibco, New York, NY, USA), F-12 Nutrient Mixture (HAM, Gibco, New York, NY, USA) (2:1), supplemented with $10 \%$ Fetal Clone III bovine serum (Hyclone, Logan, Utah, USA), penicillin $(100 \mathrm{U} / \mathrm{mL})$, streptomycin $(100 \mu \mathrm{g} / \mathrm{mL})$, gentamicin $(50 \mu \mathrm{g} / \mathrm{mL})$, amphotericin B $(2.5 \mu \mathrm{g} / \mathrm{mL})$, glutamine (4 mM), adenine $(0.18 \mathrm{mM})$ (Sigma-Aldrich, St. Louis, MO, USA), insulin $(5 \mu \mathrm{g} / \mathrm{mL})$ (Sigma-Aldrich, St. Louis, MO, USA), hydrocortisone $(0.4 \mu \mathrm{g} / \mathrm{mL})$ (SigmaAldrich, St. Louis, MO, USA), cholera toxin (0.1 nM) (Sigma-Aldrich, St. Louis, MO, USA), triiodothyronine (20 pM) (Sigma-Aldrich, St. Louis, MO, USA), and epidermal growth factor (EGF) (10 ng/mL) (R\&D Systems, Minneapolis, MN, USA ${ }^{(21)}$. The cells were plated on a support layer, called feederlayer, composed of murine fibroblasts of the type 3T3-Swiss albino (ATCC/catalog number CCL-92), which were irradiated (60 Gy), and maintained in an incubator at $37^{\circ} \mathrm{C}$, in a humidified atmosphere containing $5 \% \mathrm{CO}_{2}$.

Moreover, HaCaT cells, a cell line of immortalized oral keratinocytes obtained by spontaneous transformation and provided by Dr. Decio Pinto dos Santos Jr. for this study, were grown in DMEM (Gibco, Germany) supplemented with $10 \%$ fetal bovine serum. These cells were maintained in a humidified atmosphere containing $5 \% \mathrm{CO}_{2}$ at $37^{\circ} \mathrm{C}$.

\section{DNA extraction and STR profiling}

In order to confirm the identity of the squamous cell carcinoma cell lines used in this study, STR profiling was performed. The same technique could not be applied to Fadu and $\mathrm{HaCaT}$ cell lines since standard profiles for these cells were not available.

For this analysis, the DNA was isolated from cells with the Puregene Isolation kit (Qiagen), according to the manufacturer's protocol. The extracted DNA was amplified by polymerase chain reaction (PCR), according to the AmpFLSTR Identifiler ${ }^{\circledast}$ kit manual (Life Technologies). The loci analyzed were: amelogenin, D7S820, D5S818, TPOX, CSFPO1, vWA, D13S317, TH01, and D16S539. The choice of these markers was based on the characteristics provided by ATCC for our cell lines, as shown in Chart 1. PCR products were separated by capillary electrophoresis in denaturing conditions using the ABI Prism 3130 Genetic Analyzer (Life Technologies), and results were evaluated using the analysis software Gene Mapper 3.7 (Life Technologies)

Chart 1. STR used by the ATCC to characterize cell lines derived from squamous cell carcinoma of the tongue and selected for this study

\begin{tabular}{|c|c|c|c|}
\hline $\begin{array}{l}\text { STRs } \\
\text { AmpFLSTRIdentifiler }\end{array}$ & SCC4 & SCC9 & SCC25 \\
\hline D7S820 & 9,11 & 8 & 12 \\
\hline CSF1PO & 11 & 11 & 10 \\
\hline TH01 & 9.3 & 8,9 & 8 \\
\hline D13S317 & 11,13 & 9 & 13 \\
\hline D16\$539 & 12 & 10,11 & 11,12 \\
\hline vWA & 15,17 & 17 & 17,19 \\
\hline TPOX & 8 & 9,11 & 8,12 \\
\hline Amelogenin & $X, Y$ & $X, Y$ & $x$ \\
\hline D5S818 & 13 & 12 & 12 \\
\hline
\end{tabular}


at the Laboratório de Técnicas Especiais do Hospital Israelita Albert Einstein (HIAE).

\section{RNA Extraction}

Total RNA was extracted using the miRVana miRNA isolation kit (Ambion), according to the manufacturer's instructions. RNA concentrations were determined using the spectrophotometer NanoVue (GE Healthcare, Munich, Germany), and RNA integrity was verified on agarose gels.

\section{Real-time PCR to evaluate miRNA expression}

For detection of miRNA expression, the reverse transcription was performed from samples of total RNA (TaqMan MicroRNA Reverse Transcription Kit, Life Technologies, Foster City, CA), followed by a realtime PCR reaction with specific commercial primers (TaqMan MicroRNA Assays, Life Technologies, Foster City, CA). All assays strictly followed the manufacturer's recommendations and were performed in duplicate. RNU48, a small RNA with abundant and relatively stable expression in human tissue was used as endogenous control for normalization ${ }^{(22)}$. The expression results were presented as the normalized expression ratio (fold-change) between cell lines and primary cultured oral keratinocytes ${ }^{(23)}$.

\section{RESULTS}

Tongue squamous cell carcinoma cell lines (SCC4, SCC9, and SCC25) were submitted STR profiling comprising nine gene loci. The choice of loci was based on standard profiles provided by ATCC. STR profiles were analyzed using the AmpFLSTR Identifiler ${ }^{\circledR}$ kit (Life Technologies). The three cell lines showed the

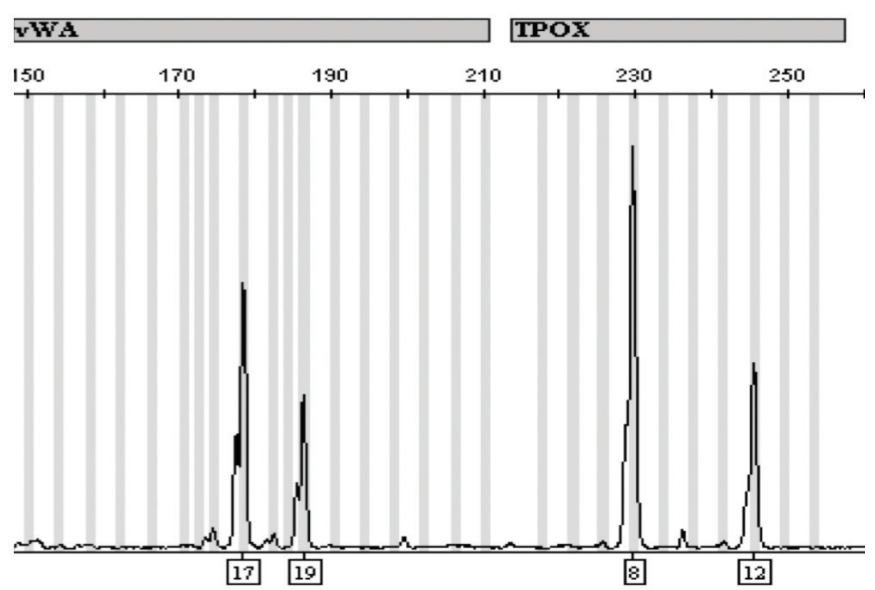

Figure 1. Representation of the STR identified in SCC25
STR pattern described by ATCC, indicating that these cells probably retain the characteristics of the original cell line. Figure 1 illustrates results of this analysis for the SCC25 cell line.

As for the primary culture of oral keratinocytes, experiments were performed to determine if the presence of the support layer (feeder-layer) could interfere with the expression levels of the miRNAs of interest for this study. Thus, we analyzed the relative expression of miRNAs in keratinocytes still in the presence of abundant feeder layer (BHKFL), and in a confluent culture of keratinocytes (BHK3) (Figure 2). In BHKFL, the keratinocytes were sub confluent and occupied about $70 \%$ of the culture plate, whereas in BHK3, they occupied $98 \%$ of the plate. The expression of the studied miRNAs remained constant or increased as the quantity of the feeder layer decreased. The expression of these miRNAs was also compared between irradiated and non-irradiated fibroblasts and it was found that the expression in the feeder layer is not null. We decided to perform subsequent experiments in BHK3 like conditions.

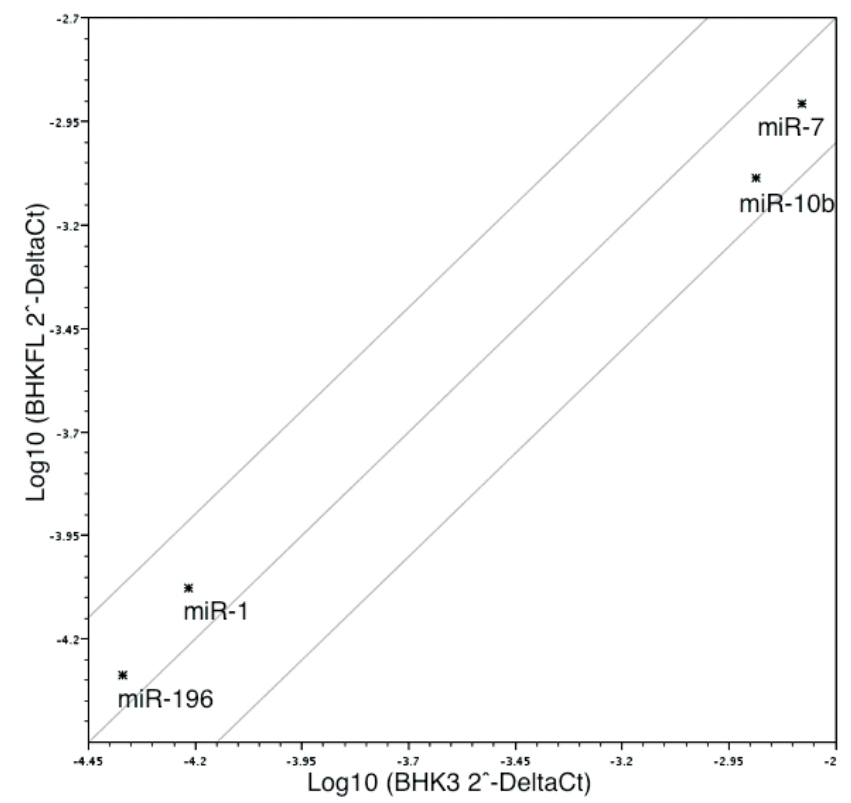

Figure 2. Scatter plot comparing miRNA expression levels between confluent (BHK3) and nonconfluent (BHKFL) keratinocytes. The graph plots the average log10 fold-change values of miRNA expression obtained by real-time PCR analysis

The basal level of expression of the four miRNAs of interest in squamous cell carcinoma cell lines compared with oral keratinocytes can be seen in Figure 3. The expression of miR-196 was significantly higher in tumor cell lines, as compared to its expression in normal cells. It is noteworthy, however, that the expression was also higher in the cell line of immortalized oral keratinocytes $(\mathrm{HaCaT})$, indicating that this cell line would not be an 
appropriate non-tumor cell model for this miRNA. The same pattern is observed for miR-10b: originally poorly expressed in tumor samples, as compared to tumorfree tissue, it is also less expressed in tumor cell lines, as compared to normal oral keratinocytes. However, miR-10b expression in $\mathrm{HaCaT}$ cells is not comparable to the expression in normal oral keratinocytes from primary cultures.

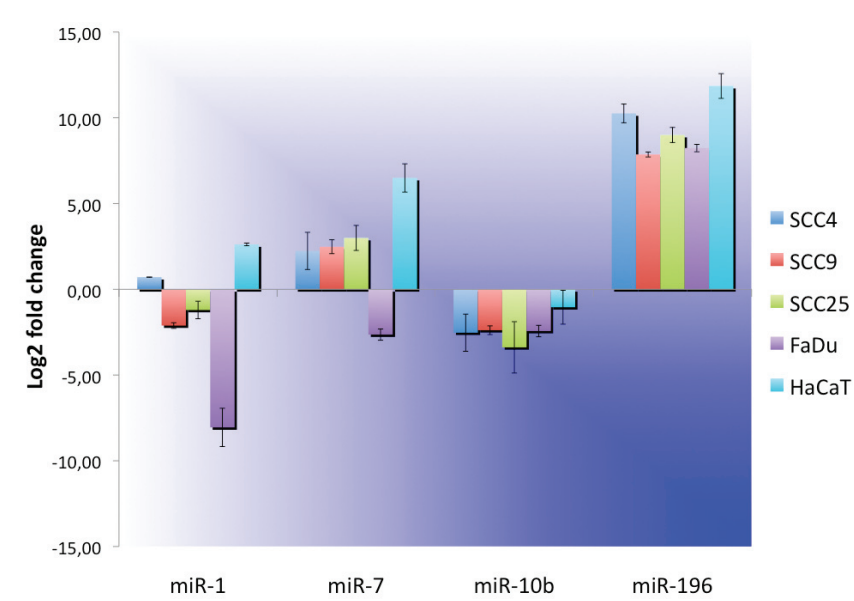

Figure 3. Expression levels of miRNAs in cell lines as compared to a primary culture of keratinocytes. The graph plots the average log2 fold-change values of miRNA expression obtained by real-time PCR analysis. SCC4, SCC9, SCC25: tongue squamous cell carcinoma cell lines; FaDu: squamous cell carcinoma of the hypopharynx cell line; HaCaT: spontaneously immortalized keratinocyte cell line; BHK3: confluent keratinocytes

Less consistent results, emphasizing intrinsic properties of tumor cells, were obtained for miR-7 and miR-1, which were respectively over expressed and poorly expressed in tumors. As for miR-7, tongue carcinoma-derived cell lines showed an expected over expression when compared to normal oral keratinocytes, whereas oropharynx carcinoma cell line $\mathrm{FaDu}$ did not show the same result. Interestingly, HaCaT cells showed the highest miRNA expression, although it was expected that their expression would be lower than that of tumor cell lines. As for miR-1, the exception was the SCC4 cell line, which showed an expression higher than that of normal oral keratinocytes, although the expected expression would be lower.The miR-1 expression level was higher in $\mathrm{HaCaT}$ cells, as compared to other tumor lines, as expected for this miRNA.

\section{DISCUSSION}

Cell lines are widely used in research as models for studying molecular mechanisms in diseases, particularly in the study of cancer. Recent studies have identified cross-contamination problems as detected with STR characterization in head and neck carcinoma cell lines $^{(24)}$. Continuous monitoring of cell lines is required for purposes of quality control. Therefore, this study initially assessed cell identity in order to render the subsequent findings reliable and reproducible. For the three tongue carcinoma-derived cell lines selected for this study, STR patterns proved to be identical to those expected, according to data provided by ATCC. These results do not guarantee that genetic changes resulting from the number of passages of these cells bred in research laboratories do not interfere in the results, but attest to the original identity of the cell line and the purity of the culture.

In vitro functional studies may show different results depending on the cells used, because the genetic characteristics of the cell lines associated with the expression of the genes of interest are unknown. Therefore, it is essential to evaluate multiple possibilities before selecting the best model. In this study some differences in the expression of miRNAs among the cell lines commonly used as models for HNSCC, SCC4, SCC9, SCC25 and FaDu, were demonstrated. The behavioral differences among the cell lines used in this study were observed by several authors. The group of Kim et al. ${ }^{(25)}$ observed that the cell line SCC4 had lower levels of cell proliferation and survival when compared to cell lines SCC9 and SCC25 after treatment with celecoxib (an anti-inflammatory drug). Chou et al. ${ }^{(26)}$ showed that involucrin (an epidermal differentiation marker protein) was not induced by hypoxia in poorly differentiated SCC4 cells, in contrast to SCC9 cells. In the study by Liang et al. ${ }^{(27)}$, treatment with the extract of marine corals showed great potential for inhibition of cell growth and induction of differentiation in SCC25 cells, moderate differentiation in SCC9 cells, and low differentiation in SCC4 cells. These studies underscore the importance of selecting an appropriate model for studies on cell lines.

Some functional studies on miRNAs have been performed with head and neck squamous cell carcinoma-derived cells. In the study by $\mathrm{Li}$ et al. ${ }^{(11)}$, it was observed that inhibition of miR-21 induced apoptosis in tongue squamous cell carcinoma cell lines. Wong et al. ${ }^{(28)}$ demonstrated that tongue squamous cell carcinoma cell lines that overexpressed $\mathrm{miR}-133 \mathrm{a} / \mathrm{b}$ in a functional study showed lower rates of proliferation and increased apoptosis. A recent review highlighted the importance of miRNAs for head and neck cancer, as well as functional studies performed in cell lines ${ }^{(29)}$. Our results indicate that the impact of overexpression or inhibition of expression of a given miRNA can vary depending on the cell used as a study model, and this can interfere in the conclusions obtained.

It is known that the gene expression in the support feeder layer used for the maintenance of oral 
keratinocytes is not null: the irradiation of fibroblasts is adequate to control cell proliferation but the effect upon other genes is unknown ${ }^{(30)}$. Despite the small variation in the expression of miRNAs in BHKFL and BHK3 (Figure 2), expression of miRNAs was identified in irradiated fibroblasts. Therefore, we believe that the expression of miRNAs in keratinocytes is best evaluated in BHK3 conditions, i.e., in confluent cultures.

The expression of the four miRNAs of interest was compared between primary culture of keratinocytes and immortalized HaCaT cell line. This cell line has been widely used in literature as a model for normal keratinocytes because it is a cell line of easy propagation and near-normal phenotype. We identified important differences in the pattern of expression of the miRNAs in these two cell cultures. Our results suggest that the use of a primary culture, despite the limitation of their lifespan and greater complexity for their maintenance in culture, should be considered for studies aimed at outcomes associated with a normal cellular phenotype.

\section{CONCLUSIONS}

Our results showed significant differences in gene expression among the cell lines that can be used as models for functional studies on miRNAs in head and neck squamous cell carcinoma. Some differences between tongue and pharynx squamous cell carcinoma cell lines were observed, as well as significant differences between a cell line of immortalized oral keratinocytes, $\mathrm{HaCaT}$, and normal oral keratinocytes from primary cultures. We conclude that careful selection of cell lines is essential to accurate conclusions about the role of miRNAs in tumors.

\section{ACKNOWLEDGMENTS}

We thank the Laboratory for Special Techniques (LATE) of HIAE for providing and performing the STR analysis. We especially thank Elena Outon Alonso, for performing the assay. This study was funded by The State of São Paulo Research Foundation (FAPESP) (2009/04166-5). Flavia Maziero Andreghetto receives a master's degree grant from the Coordination for the Improvement of Higher Education Personnel (CAPES).

\section{REFERENCES}

1. Vermorken JB, Mesia R, Rivera F, Remenar E, Kawecki A, Rottey S, et al. Platinum-based chemotherapy plus cetuximab in head and neck cancer. $\mathrm{N}$ Engl J Med. 2008;359(11):1116-27.

2. Jemal A, Siegel R, Xu J, Ward E. Cancer statistics, 2010. CA Cancer J Clin. 2010;60(5):277-300.
3. Farshadpour F, Kranenborg H, Calkoen EV, Hordijk GJ, Koole R, Slootweg PJ, et al. Survival analysis of head and neck squamous cell carcinoma: influence of smoking and drinking. Head Neck. 2011;33(6):817-23.

4. Basu R, Mandal S, Ghosh A, Poddar TK. Role of tobacco in the development of head and neck squamous cell carcinoma in an eastern Indian population. Asian Pac J Cancer Prev. 2008;9(3):381-6.

5. Jemal A, Siegel R, Murray T, XU J, Thun MJ. Cancer statistics. CA Cancer J Clin. 2007;57(1):34-66.

6. Greenman J, Homer JJ, Stafford N. Markers in cancer of the larynx and pharynx. Clin Otolaryngol Allied Sci. 2000;25(1):9-18.

7. Lagos-Quintana M, Rauhut $R$, Lendeckel W, Tuschl T. Identification of novel genes coding for small expressed RNAs. Science. 2001;294(5543):853-8.

8. Hwang HW, Mendell JT.MicroRNAs in cell proliferation, cell death, and tumorigenesis. Br J Cancer. 2007;96(Suppl):R40-4.

9. Stefani G, Slack FJ. Small non-coding RNAs in animal development. Nat Rev Mol Cell Biol. 2008;9(3):219-30.

10. Lewis BP, Shih $\mathbb{H}$, Jones-Rhoades MW, Bartel DP, Burge CB. Prediction of mammalian microRNA targets. Cell. 2003;115(7):787-98.

11. Li J, Huang H, Sun L, Yang M, Pan C, Chen W, et al. MiR-21 indicates poor prognosis in tongue squamous cell carcinomas as an apoptosis inhibitor. Clin Cancer Res. 2009;15(12):3998-4008.

12. Langevin SM, Stone RA, Bunker CH, Lyons-Weiler MA, Laframboise WA, Kelly $L$, et al. MicroRNA-137 promoter methylation is associated with poorer overall survival in patients with squamous cell carcinoma of the head and neck. Cancer. 2011;117(7):1454-62.

13. Gee HE, Camps C, Buffa FM, Patiar S, Winter SC, Betts G, et al. Hsa-mir-210 is a marker of tumor hypoxia and a prognostic factor in head and neck cancer. Cancer. 2010;116(9):2148-58.

14. Alston-Roberts C, Barallon R, Bauer S, Butler J, Capes-Davis A, Dirks W, et al. Cell line misidentification: the beginning of the end. Nat Rev Cancer. 2010;10(6):441-8.

15. Oldroyd NJ, Urquhart AJ, Kimpton CP, Millican ES, Watson SK, Downes T, et al. A highly discriminating octoplex short tandem repeat polymerase chain reaction system suitable for human individual identification. Electrophoresis. 1995;16(3):334-7.

16. Yan D, Dong Xda E, Chen X, Wang L, Lu C, Wang J, et al. MicroRNA-1/206 targets c-Met and inhibits rhabdomyosarcoma development. J Biol Chem. 2009;284(43):29596-604.

17. Li Y, Zhang M, Chen H, Dong Z, Ganapathy V, Thangaraju M, et al. Ratio of miR196s to HOXC8 messenger RNA correlates with breast cancer cell migration and metastasis. Cancer Res. 2010;70(20):7894-904.

18. Gabriely G, Yi M, Narayan RS, Niers JM, Wurdinger T, Imitola J, et al. Human glioma growth is controlled by microRNA-10b. Cancer Res. 2011;71(10):3563-72.

19. Saydam 0, Senol O, Wurdinger T, Mizrak A, Ozdener GB, Stemmer-Rachamimov $A 0$, et al. miRNA-7 attenuation in Schwannoma tumors stimulates growth by upregulating three oncogenic signaling pathways. Cancer Research. 2011;71(3):852-61.

20. Klingbeil MFG, Herson MR, Cristo EB, Pinto Jr DS, Yoshito D, Mathor MB. Comparasion of two cellular harvesting methods for primary human oral culture of keratinocytes. Cell Tissue Bank. 2009;10(3):197-204.

21. Benassi L, Marconi A, Sevignani C, Vaschieri C, Zambruno G. Metodiche di coltura di cheratinociti umani normali. In: Zambruno G, Canceda R, De Luca M, Andreassi L. Coltura di cheratinociti umani normali e loro applicazione. Workshop di Biologia Cellulare e Immunologia della Cute. Modena: Universitá deli Studi di Modena; 1993. p. 5-23.

22. Duan Z, Choy E, Nielsen GP, Rosenberg A, lafrate J, Yang C, et al. Differential expression of microRNA (miRNA) in chordoma reveals a role for miRNA-1 in Met expression. J Orthop Res. 2010;28(6):746-52. 
23. Arocho A, Chen B, Ladanyi M, Pan Q.Validation of the 2-DeltaDeltaCt calculation as an alternate method of data analysis for quantitative PCR of BCR-ABL P210 transcripts. Diagn Mol Pathol. 2006;15(1):56-61.

24. Schweppe RE, Klopper JP, Korch C, Pugazhenthi U, Benezra M, Knauf JA, et al. Deoxyribonucleic acid profiling analysis of 40 human thyroid cancer cell lines reveals cross-contamination resulting in cell line redundancy and misidentification. J Clin Endocrinol Metab. 2008:93(11):4331-41.

25. Kim YY, Lee EJ, Kim YK, Kim SM, Park JY, Myoung H, et al. Anti-cancer effects of celecoxib in head and neck carcinoma. Mol Cells. 2010;29(2):185-94.

26. Chou SC, Azuma Y, Varia MA, Raleigh JA. Evidence that involucrin, a marker for differentiation, is oxygen regulated in human squamous cell carcinomas. $\mathrm{Br}$ $\mathrm{J}$ of Cancer. 2004;90(3):728-35.
27. Liang $\mathrm{CH}$, Wang GH, Hung WJ, Lin RJ, Cheng DL, Cho TH. Apoptosis effect of Sinularialeptoclados, S. depressan and $\mathrm{S}$. inflate extracts in human oral squamous cell carcinomas. J Taiwan Inst Chem Eng. 2010;41(1):86-91.

28. Wong TS, Liu XB, Chung-Wai AH, Po-Wing AY, Wai-Man R, Ignace WW. Identification of pyruvate kinase type $\mathrm{M} 2$ as potential oncoprotein in squamous cell carcinoma of tongue through microRNA profiling. Int J Cancer. 2008;123(2):251-7.

29. Tran N, O'Brien CJ, Clark j, Rose B. Potential role of micro-RNAs in head and neck tumorigenesis. Head Neck. 2010;32(8):1099-111.

30. Pollard EC, Lydersen BK. The action of ionizing radiation on the synthesis of RNA and two inducible enzymes in Escherichia coli. Radiat Res. 1972;50(2):293-300. 